\title{
Circadian Rhythm of Intestinal Sucrase Activity in Rats
}

\author{
MECHANISM OF ENZYME CHANGE
}

\author{
Mark A. Kaufman, Helen A. Korsmo, and Ward A. Olsen, Gastroenterology \\ Research Laboratory, William S. Middleton Memorial Veterans Administration \\ Hospital and Department of Medicine, Center for Health Sciences, University \\ of Wisconsin, Madison, Wisconsin 53706
}

A B S T R A C T Past investigation has revealed that the circadian rhythm of intestinal sucrase activity in rats is primarily cued by the time of feeding. We examined the mechanism of the circadian rhythm by methods involving quantitative immunoprecipitation of sucraseisomaltase protein and study of decay of radioactively labeled protein. Rats were placed on a controlled feeding regimen (1000-1500 h) and then sacrificed at 3-h intervals over a 24 -h period. Immunotitration experiments indicated that the circadian rhythm was the result of changes in the absolute amount of sucrase-isomaltase protein present and not of changes in the enzyme's catalytic efficiency.

To study the mechanism of this circadian variation in sucrase-isomaltase mass, $\left[{ }^{14} \mathrm{C}\right]$ sodium carbonate was injected and, after maximum incorporation into brush border protein, the rats were sacrified at 3-h intervals. Sucrase-isomaltase protein was isolated by immunoprecipitation, and the decrease in total disintegrations per minute over time was used to study degradation of the protein. Enzyme degradation was not constant but exhibited a clear circadian rhythm. The period of increasing enzyme mass was characterized by virtual cessation of enzyme degradation $\left(t_{1 / 2}\right.$ of $38 \mathrm{~h}$ ), and the period of declining enzyme mass by rapid degradation ( $t_{1 / 2}$ of $6 \mathrm{~h}$ or less). We found similar changes in enzyme degradation in fasted animals, demonstrating that the changes were not the result of decreased isotope reutilization during feeding. We found no evidence of a circadian rhythm in $\left[{ }^{14} \mathrm{C}\right]$ leucine incorporation into the protein, suggesting that enzyme synthesis was constant.

These results indicate that the circadian rhythm of sucrase activity represents changes in the total amount of enzyme protein that are, at least in large part, secondary to changes in the enzyme's degradation rate.

Received for publication 24 January 1979 and in revised form 18 January 1980.

\section{INTRODUCTION}

A number of studies have demonstrated a circadian rhythm in the activities of intestinal disaccharidases (1-5). That the circadian rhythm of sucrase activity in rats is synchronized by the time of feeding, but not by the lighting rhythm, has also been clearly established (2-5). A significant rise in enzyme activity usually occurs $1 \mathrm{~h}$ before onset of feeding with continued elevated levels throughout the feeding period. Activity begins to decrease within 1-3 h after feeding ceases. This rhythm can be temporally shifted by altering the time of controlled feeding (5), but can be eliminated only by several days of starvation (2). Because most investigators have found a rise in enzyme activity $1 \mathrm{~h}$ before the scheduled beginning of feeding, many have postulated that it is the anticipation of feeding that triggers the rise in enzyme activity rather than food intake itself. This suggestion is supported by the observation that the rhythm persists for at least $2 \mathrm{~d}$ during starvation (2).

We studied the mechanism of this circadian rhythm of sucrase activity. We used quantitative immunoprecipitation to determine whether increased enzyme activity during feeding resulted from an absolute increase in the amount of enzyme protein present or from a change in the proportions of active and inactive enzyme. We also studied incorporation of isotopically labeled precursor into sucrase-isomaltase protein to look for evidence of a circadian rhythm of either enzyme degradation or synthesis. Our findings indicate that the circadian rhythm of intestinal sucrase activity represents changing enzyme protein levels that appear to be the consequence of changing degradation rates.

\section{METHODS}

Male Sprague-Dawley rats (Madison, Wis.) weighing 75$150 \mathrm{~g}$ were placed on a controlled feeding regimen made 
available from 1000 to $1500 \mathrm{~h}$ only, with a standard diet that included carbohydrate. After 1-2 wk on this feeding regimen, animals were sacrificed at appropriate intervals for study of solubilized sucrase-isomaltase as described below.

Enzyme solubilization. The following procedures were done at $4^{\circ} \mathrm{C}$. The animals were stunned, decapitated, and the abdominal cavity opened with prompt removal of the small intestine from the ligament of Treitz to the cecum. The intestine was rinsed with normal saline, flushed with saline, everted, rinsed again, and then scraped over ice with a glass slide to remove the mucosa. After adding $0.1 \mathrm{M}$ potassium phosphate buffer $\mathrm{pH} 7.4(5 \mathrm{ml} / \mathrm{g}$ mucosa), mucosa from each rat was homogenized over ice for 10 and then $15 \mathrm{~s}$ with a Polytron homogenizer at setting No. 4 (Brinkmann Instruments, Inc., Westbury, N. Y.). Papain and cysteine were each added in amounts of $0.2 \mathrm{mg} / \mathrm{ml}$ of homogenate, and the homogenates were then incubated at $37^{\circ} \mathrm{C}$ for $60 \mathrm{~min}$, followed by centrifugation for $60 \mathrm{~min}$ at $105,000 \mathrm{~g}$ at $4^{\circ} \mathrm{C}$. (Addition of the protease inhibitor phenylmethyl sulfonyl fluoride at a concentration of $0.5 \mathrm{mg} / \mathrm{ml}$ after $60 \mathrm{~min}$ of incubation with papain and its inclusion during immunoprecipitation did not affect the pattern found on sodium dodecyl sulfate-acrylamide gel electrophoresis of immunoprecipitates, so that a protease inhibitor was not used.) Resultant supernatant fractions were dialyzed overnight at $4^{\circ} \mathrm{C}$ against $0.1 \mathrm{M} \mathrm{KPO}_{4}$ buffer, $\mathrm{pH}$ 7.4. The dialyzed supernatant fractions will be referred to as papain supernates. Recovery of homogenate sucrase activity in papain supernates was not different between periods of high and low activity ( 89 vs. $87 \%$ ).

Sucrase-isomaltase immunoprecipitation. Purification of sucrase-isomaltase for raising antibodies was done as described by Kolínská and Kraml (6). We have previously shown (7) that the purified protein was homogeneous by acrylamide gel electrophoresis at two $\mathrm{pHs}$; the protein was also homogeneous by analytical ultracentrifugation. Preparation of the rabbit antiserum was done as described by Olsen and Korsmo (7). Although the antiserum precipitated $100 \%$ of sucrase activity in papain supernates under conditions of antibody excess, it precipitated no lactase or leucylnaphthylamidase activity.

To isolate sucrase-isomaltase protein, the optimal relative amounts of antiserum and enzyme activity were determined by double diffusion in agar gel as described by Ouchterlony (8). Quantitative precipitin reactions were carried out as per Kabat and Meyer (9). In practice, $0.01 \mathrm{ml}$ of antiserum was added to aliquots of papain supernate from two different groups of rats that had significantly different sucrase specific activities. These aliquots contained identical amounts of enzyme activity ranging from 0.05 to $0.30 \mathrm{U}(1 \mathrm{U}=1 \mu \mathrm{mol}$ of sucrose hydrolyzed $/ \mathrm{min}$ ) and were then made up to identical volumes with isotonic saline. The tubes were held at $4^{\circ} \mathrm{C}$ for $2 \mathrm{~d}$ and then centrifuged at $1,000 \mathrm{~g}$ for $15 \mathrm{~min}$ at $4^{\circ} \mathrm{C}$. The pellet was washed three times with normal saline and then assayed for protein (10). The supernates obtained after the initial centrifugation (before washing) were assayed for sucrase activity. The quantity of protein present in the antigen-antibody precipitate and the amount of sucrase activity present in the papain supernate for each rat were plotted against the amount of original enzyme. All the above was done in duplicate.

Isotopic decay of labeled sucrase-isomaltase. Proteins were labeled by tail-vein injection of $500 \mu \mathrm{Ci}$ of $\left[{ }^{14} \mathrm{C}\right]$ sodium carbonate $(2-10 \mathrm{mCi} / \mathrm{mmol} \mathrm{sp}$ act, New England Nuclear, Boston, Mass.). Unless specifically stated, the usual 1000$1500 \mathrm{~h}$ access to food was provided during these experiments. Preliminary studies indicated that maximum labeling of sucrase-isomaltase under these conditions was achieved by $14 \mathrm{~h}$ so that, beginning $14 \mathrm{~h}$ after injection, the rats were sacrificed at 3-h intervals (four rats per interval) and papain supernates prepared from individual animals. Sucrase-isomaltase protein was isolated in duplicate by adding $0.08 \mathrm{ml}$ of antiserum to solutions containing $1.664 \mathrm{U}$ of sucrase activity made up to identical volumes with saline for each rat, and the pellet obtained after washing was dissolved in $0.2 \mathrm{ml}$ of Bio-Solv, formula BBS-3 (Beckman Instruments, Inc., Fullerton, Calif.). Scintillation fluid consisted of $6 \mathrm{ml}$ of a solution of toluene, Liquifluor (New England Nuclear.), and alcohol (1,000:42: $379 \mathrm{ml}$, respectively). Each sample was counted for $20 \mathrm{~min}$ at $\sim 70 \%$ efficiency in a Packard Tri-Carb liquid scintillation spectrometer, model 3330 (Packard Instruments Co., Inc., Downers Grove, Ill.). Acrylamide gel electrophoresis of the immunoprecipitates in the presence of sodium dodecyl sulfate with counting of gel slices demonstrated that $\sim 90 \%$ of precipitated counts migrated with sucrase-isomaltase subunits (determined by simultaneous electrophoresis of the isolated protein). Analysis of the original supernate for sucrase failed to reveal significant residual enzyme activity, indicating essentially total precipitation of the enzyme.

To correct for nonspecific precipitation (11), $1.664 \mathrm{U}$ of nonradioactive sucrase was added to the papain supernates after removal of immunoprecipitates. Immunoprecipitation with $0.08 \mathrm{ml}$ of antiserum was repeated, and the radioactivity measured in the pellets. Nonspecific precipitate radioactivity was relatively constant and averaged $44 \pm 3$ (SEM) dpm, whereas the radioactivity of sucrase-isomaltase decreased markedly with time from injection. In addition, the supernate from the nonspecific immunoprecipitation was also checked for sucrase activity to ensure complete immunoprecipitation. After subtracting nonspecific precipitation, the radioactivity "disintegrations per minute" of sucrase-isomaltase was plotted against time on semilogarithmic paper. Half-lives were calculated by linear regression. Differences in slopes of lines were statistically compared with methods outlined by Goldstein (12).

The radioactivity of total proteins in papain supernates was determined by the technique of Siekevitz (13). In duplicate runs, trichloroacetic acid was added to precipitate protein; nucleic acid was then removed with hot trichloroacetic acid and lipid with alcohol-ether-chloroform and ether. The final air-dried residue was dissolved in $300 \mu$ l of $0.3 \mathrm{~N}$ sodium hydroxide for determination of protein and radioactivity.

Incorporation of $\left[{ }^{14} \mathrm{C}\right]$ leucine into sucrose-isomaltase. To provide evidence that might support a circadian rhythm in enzyme synthesis, we studied incorporation of $\left[{ }^{14} \mathrm{C}\right]$ leucine into sucrase-isomaltase. Animals were injected with $20 \mu \mathrm{Ci}$ of $\left[{ }^{14} \mathrm{C}\right]$ leucine $\left(\mathrm{L}-\left[1-{ }^{14} \mathrm{C}\right]\right.$ leucine, $>50 \mu \mathrm{Ci} / \mathrm{mmol} \mathrm{sp}$ act, New England Nuclear) by tail vein at a time of low enzyme activity $(0130 \mathrm{~h})$ and at a time of rising activity $(0930 \mathrm{~h}) .10$ and $60 \mathrm{~min}$ later, animals were sacrificed and sucrase-isomaltase and total papain supernate radioactivity determined as described above.

Enzyme assays and statistical evaluation. Disaccharidase activity was determined by the method of Dahlqvist (14), and leucylnaphthylamidase activity as described by Porteous and Clark (15). All assays were done in duplicate. Statistical evaluation of differences between means was done by $t$ test.

Determination of specific activity of free amino acids. Aliquots of individual mucosal homogenates containing $5 \mathrm{mg}$ of protein were pooled for each time point after injection of $\left[{ }^{14} \mathrm{C}\right]$ sodium carbonate. To each milliliter of pooled homogenate, $100 \mu \mathrm{l}$ of $50 \mathrm{~g} / 100 \mathrm{ml}$ sulfosalicylic acid was added over ice. After mixing and removal of the precipitate, the supernatant $\mathrm{pH}$ was adjusted to 2.2 with $4 \mathrm{~g} / 100 \mathrm{ml}$ lithium hydroxide and amino acid analysis performed by the method of Stein and Moore (16). Separate runs were performed for separation of amino acids for isotope counting by the methods described above. 


\section{RESULTS}

Sucrase activity. Under the controlled feeding regimen, a circadian rhythm of sucrase activity in both mucosal homogenates and papain supernates was found corresponding to the time of feeding (Fig. 1). Table I demonstrates that enzyme activity during a 6 -h period preceding feeding $(0300-0900 \mathrm{~h})$ is statistically different from that during a 6 -h period encompassing feeding $(1200-1800 \mathrm{~h})$. Both total activity and specific activity were significantly elevated during feeding with $P$ $<0.001$ in each case.

Immunoprecipitation experiments. We studied individual papain supernates from three animals sacrificed at $0600 \mathrm{~h}$ (low enzyme specific activity) and from three animals sacrified at $1500 \mathrm{~h}$ (high enzyme specific activity), $(0.218 \pm 0.023 \mathrm{U} / \mathrm{mg}, \mathrm{SEM}$ vs. $0.306 \pm 0.017 \mathrm{U} /$ $\mathrm{mg}, P<0.02)$. Ouchterlony double-diffusion plate analysis (8) was performed with $0.25 \mu \mathrm{l}$ of antiserum in the center well and one of the six papain supernates, each containing $0.0052 \mathrm{U}$ of sucrase activity in each of the peripheral wells. We found a single precipitin band, suggesting the presence of a single antigenic protein in the six papain supernates reactive with the antiserum.

Fig. 2 represents the results of quantitative immunoprecipitation reactions done with these six papain su-

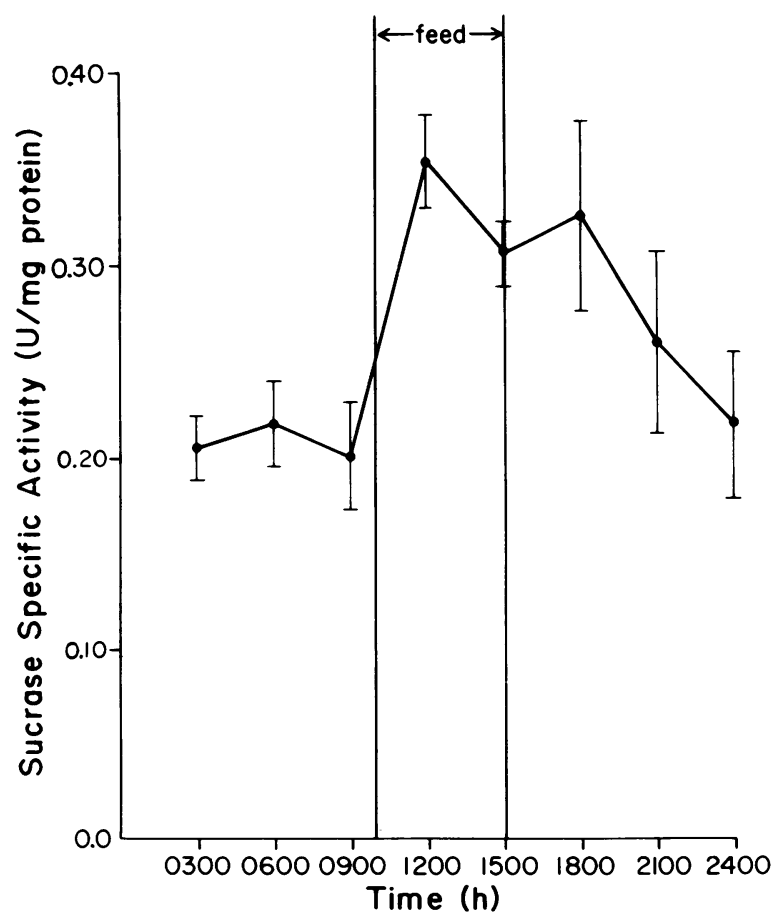

FIgURE 1 The circadian rhythm of sucrase specific activity in papain supernates. Enzyme activity rose during the feeding period, $1000-1500 \mathrm{~h}$. Mean values from four animals \pm SEM are shown.
TABLE I

Sucrase Activity of Papain Supernates

\begin{tabular}{ccc}
\hline \multicolumn{1}{c}{ Group } & Total activity & Specific activity \\
\hline & $\mu$ mol/min/animal & $\mu$ mol/min/mg protein \\
$0300-0900 \mathrm{~h}$ & $8.67 \pm 0.89$ & $0.208 \pm 0.012$ \\
$1200-1800 \mathrm{~h}$ & $16.03 \pm 1.40$ & $0.328 \pm 0.018$ \\
$\begin{array}{c}\text { Significance of } \\
\text { difference* }\end{array}$ & $P<0.001$ & $P<0.001$ \\
\hline
\end{tabular}

Means \pm SEM are given.

$* t$ test.

pernates. All sucrase activity was precipitated until the equivalence point was reached, $(0.15 \mathrm{U})$, at which time sucrase activity in the supernate increased secondary to antigen excess. The equivalence points were the same in both groups of animals, indicating that enzyme activity per unit of immunologically identified protein was not significantly different.

Isotopic decay of labeled sucrase-isomaltase. Fig. 3 demonstrates the decline in radioactivity of sucraseisomaltase in studies between 0500 and $1700 \mathrm{~h}$. Total radioactivity of sucrase-isomaltase for each animal rather than specific radioactivity is presented because of the presence of nonsteady-state conditions (17). An abrupt change in the slope of the sucrase-isomaltase decay curve occurred at $1100 \mathrm{~h}$. Before that time (during the period of rising enzyme activity), enzyme protein degradation was slow with a $t_{1 / 2}$ of $38 \mathrm{~h}$; thereafter (during the period of falling enzyme activity), degradation was rapid with a $t_{1 / 2}$ of $6 \mathrm{~h}$. In contrast to sucraseisomaltase, degradation of total proteins solubilized by papain was characterized by a single and relatively slow rate $\left(t_{1 / 2}\right.$ of $\left.23 \mathrm{~h}\right)$.

To confirm the observation of two distinct rates of degradation of sucrase-isomaltase and to determine the time at which the rapid degradation associated with feeding ceased, we studied the decline in labeled enzyme between 2000 and 1100 h. Fig. 4 demonstrates again the presence of two slopes in the curve describing degradation of sucrase-isomaltase, with an abrupt change at about $0200 \mathrm{~h}$. Thus, rapid degradation of the enzyme began at about $1100 \mathrm{~h}$ in association with feeding and continued until $\sim 0200 \mathrm{~h}$; after $0200 \mathrm{~h}$ degradation virtually stopped.

To evaluate the direct effects of food intake on sucrase-isomaltase degradation, a similar study was performed on fasted rats allowed free access to drinking water only. (The animals sacrificed for the initial time point had been fasting for $29 \mathrm{~h}$ ). We found, as others have reported (2), that a circadian rhythm of sucrase activity persists even during a short-term fast. We also found, as shown by Fig. 5, clear evidence that the rhythm continues to be accompanied by a changing pattern of degradation. Fasting appeared to have some 


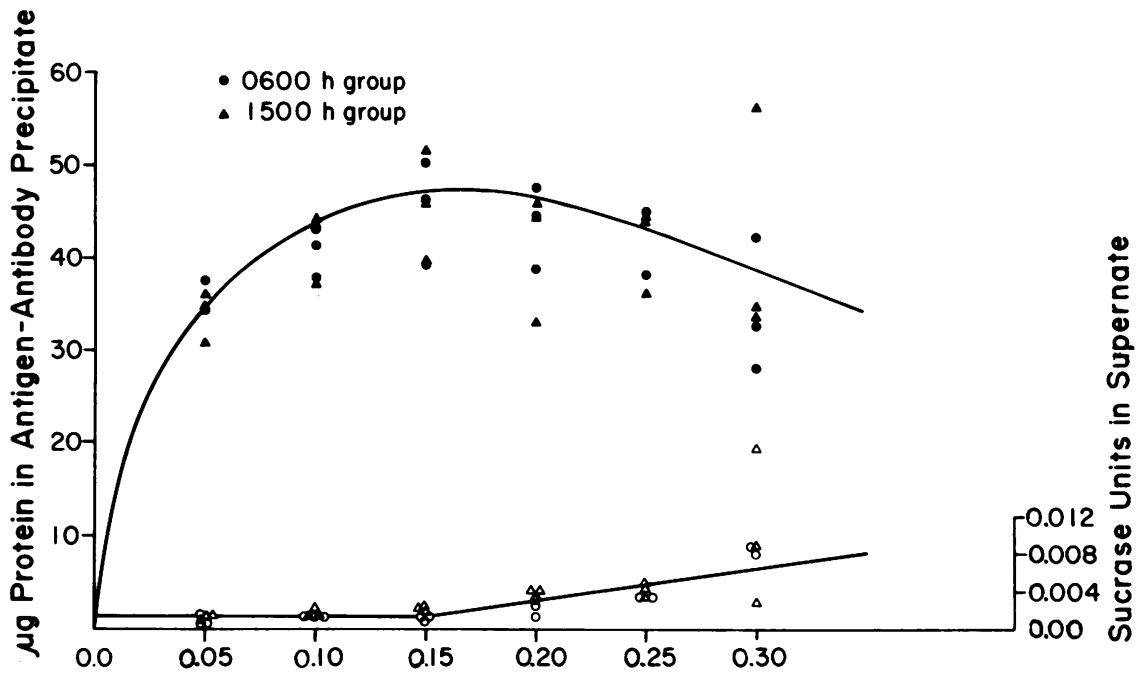

Sucrase Units Added

FIGURE 2 Quantitative immunoprecipitation reactions of sucrase-isomaltase in papain supernates from two groups of rats corresponding to high sucrase activity $(1500 \mathrm{~h})$ and low sucrase activity $(0600 \mathrm{~h})$. To $10 \mu \mathrm{l}$ of antiserum were added papain supernate aliquots from each of six rats containing the enzyme activities indicated. Precipitation was carried out as described in Methods. The closed symbols represent the protein content of antigen-antibody precipitates and the open symbols, the enzyme activity in the supernate after removal of the precipitate.

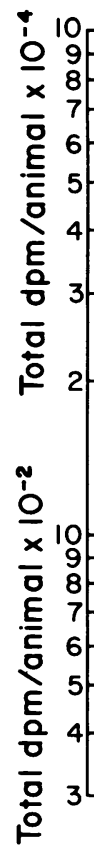

020005000800110014001700

Time of Day (h)

FIgURE 3 Degradation of sucrase-isomaltase and papainsolubilized total proteins between 0500 and $1700 \mathrm{~h}$. Mean values for four animals \pm SEM are given. Regression lines were calculated by the least squares method using individual values. The difference between the two slopes for sucraseisomaltase degradation was statistically significant $(P<0.001)$. effects on degradation, however, with the rapid phase somewhat slower than found during feeding and the time of virtual cessation of degradation occurring later (0500 instead of $0200 \mathrm{~h}$ ).

Fig. 6 shows the specific activities of free amino acids in mucosal homogenates during the study of sucraseisomaltase degradation shown in Fig. 3. The first time point was $14 \mathrm{~h}$ after injection of $\left[{ }^{14} \mathrm{C}\right]$ sodium carbonate. Specific activities of all amino acids were low and their decline with time did not seem appreciably altered during the feeding period.

Incorporation of $\left[{ }^{14} \mathrm{C}\right]$ leucine into sucrase-isomaltase. Incorporation of $\left[{ }^{14} \mathrm{C}\right]$ leucine into sucrase-isomaltase was expressed relative to incorporation into total protein to correct for possible circadian changes in precursor pool size. As shown in Table II, we found no difference in leucine incorporation into sucrase-isomaltase between a period of low and rising enzyme activity, suggesting the absence of a circadian rhythm of enzyme synthesis.

\section{DISCUSSION}

Theoretically, the circadian changes in sucrase activity could be the consequence of changes in the amount of enzyme protein present or changes in the proportions of active and inactive enzyme (18). Our immunotitration experiment, where enzyme activity was titrated against a constant amount of antiserum (Fig. 2), demonstrated that the equivalence points (beyond which en- 


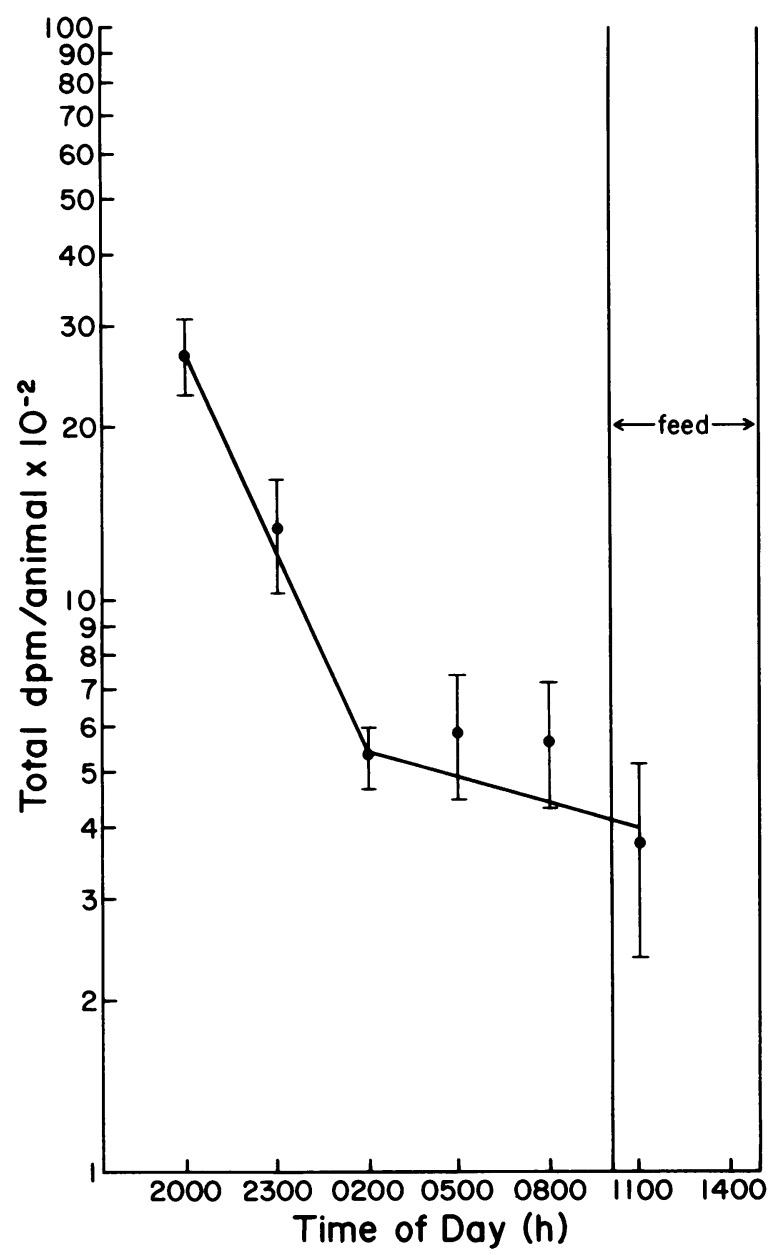

FigURE 4 Degradation of sucrase-isomaltase between 2000 and $1100 \mathrm{~h}$. Mean values for four animals \pm SEM are given. Regression lines were calculated by the least squares method. The difference between the slope of the slow component shown here (0200-1100 h) and that shown in Fig. 3 (0500$1100 \mathrm{~h}$ ) was not statistically significant. The slope of the faster component in this study (2000-0200 h) was, however, different from that component in Fig. $3(P<0.001)$, with a $t_{1 / 2}$ of 2.4 vs. $6 \mathrm{~h}$.

zyme activity was found in the supernates after centrifugation) for enzyme from animals with high sucrase activity $(1500 \mathrm{~h})$ and low activity $(0600 \mathrm{~h})$ were not significantly different. This finding indicates that the circadian changes in enzyme activity were accompanied by comparable changes in immunologically reactive enzyme protein.

The circadian rhythm of enzyme protein levels must reflect a rhythm involving enzyme synthesis, degradation, or both. We studied the degradation of sucraseisomaltase protein by measuring the radioactivity of immunoprecipitated protein after pulse-labeling by injection of ${ }^{14} \mathrm{C}$-precursor. This technique, like all techniques for assessing protein degradation, has theoretical hazards that must be discussed. The major assumptions (and potential weaknesses) in the method are that (a) the radioactivity isolated by immune precipitation represents sucrase-isomaltase rather than a contaminant and $(b)$ there is not significant reutilization of isotope (19). Both assumptions seem valid. Immune precipitation depends upon the monospecificity of the antiserum. Our antigen was homogeneous by acrylamide gel electrophoresis in two $\mathrm{pH}$ systems and by analytical ultracentrifugation. The double diffusion and quantitative immunoprecipitation experiments indicate that the resultant antiserum precipitated a homogeneous protein, a conclusion supported by the observation that it did not precipitate other brush border proteins solubilized by papain such as lactase and leucylnaphthylamidase. Finally, essentially all radioactivity of the immune precipitate (after subtraction of nonspecific isotope precipitation) migrated with sucrase-isomaltase subunits on sodium dodecyl sulfate acrylamide gel electrophoresis. Thus, immunoprecipitated radioactivity represents sucrase-isomaltase.

Reutilization of labeled amino acid precursor with apparent half-lives longer than actual half-lives has been a major problem with the use of isotope decay curves to study protein degradation (20). We therefore chose

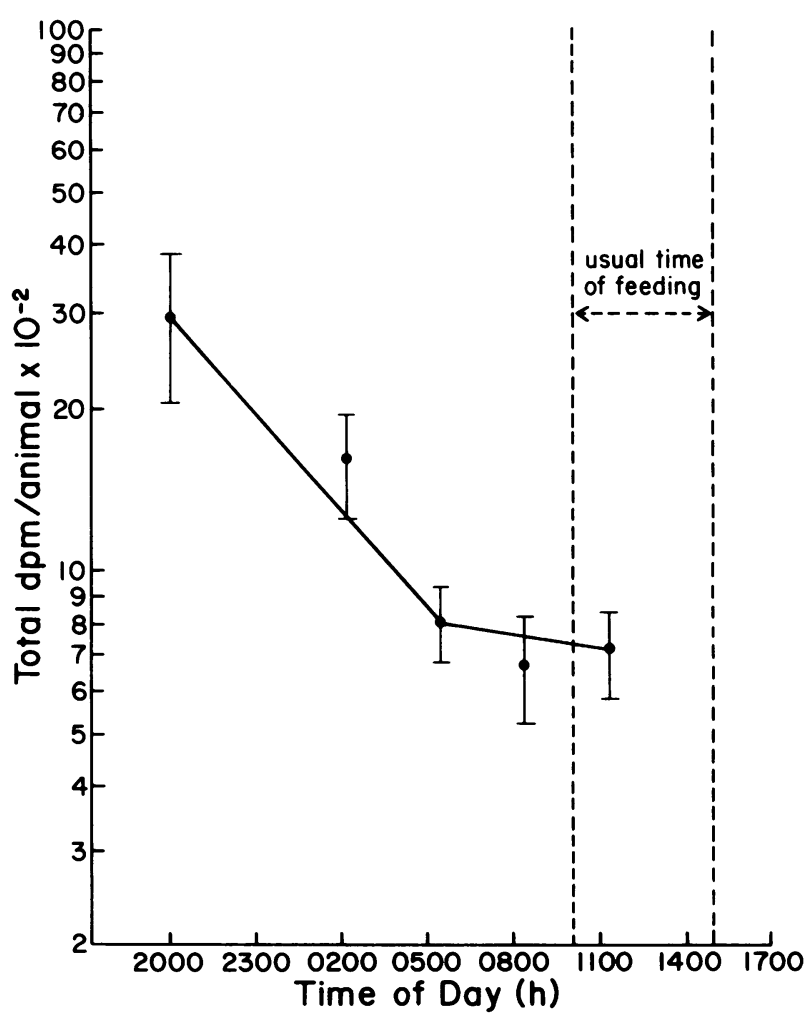

FIGURE 5 Degradation of sucrase-isomaltase in fasted animals. Mean values for four animals \pm SEM are given. Regression lines were calculated by the least squares method. 


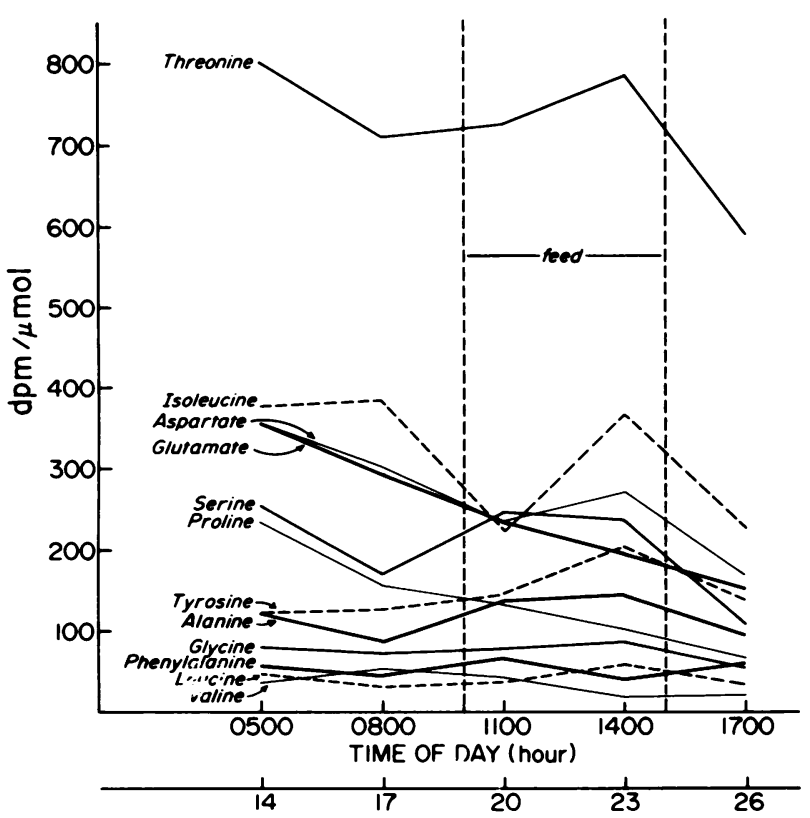

HOURS AFTER INJECTION OF $\left[{ }^{14} \mathrm{C}\right]$ SODIUM CARBONATE

FIGURE 6 Specific activity of free amino acids in mucosal homogenates during study of sucrase-isomaltase degradation. A pool of homogenates from four animals sacrificed at each time point was assayed as described in Methods. Both the time of day and the time from injection of $\left[{ }^{14} \mathrm{C}\right]$ sodium carbonate are shown. Radioactivity of amino acids not shown was negligible.

${ }^{14} \mathrm{CO}_{3}$ as a precursor to minimize reutilization. This technique has been used to study protein degradation in liver, muscle, and brain (21-24), and has been suggested as a general tool for the study of turnover of tissue proteins (20). Labeling of glutamate and aspartate after ${ }^{14} \mathrm{CO}_{3}$ injection occurs by carboxylation of pyruvate and the interconversions of the tricarboxylic acid cycle. As originally described for study of muscle protein metabolism (22), the radioactivity of protein aspar-

TABLE II

Relative Incorporation of Leucine into Sucrase-Isomaltase

\begin{tabular}{|c|c|c|}
\hline & \multicolumn{2}{|c|}{ Incorporation time } \\
\hline & $10 \mathrm{~min}$ & $60 \min$ \\
\hline Injection at $0130 \mathrm{~h}$ & $0.017 \pm 0.003(3)$ & $0.043 \pm 0.004(3)$ \\
\hline Injection at $0930 \mathrm{~h}$ & $0.025 \pm 0.004(3)$ & $0.042 \pm 0.007(3)$ \\
\hline $\begin{array}{l}\text { Significance of } \\
\text { difference* }\end{array}$ & NS & NS \\
\hline
\end{tabular}

$\left[{ }^{14} \mathrm{C}\right]$ Leucine was injected (20 $\mu \mathrm{Ci}$ i.v.) at 0130 and $0930 \mathrm{~h}$, and the animals sacrificed 10 and 60 min later. Disintegrations per minute of sucrase-isomaltase were divided by disintegrations per minute of papain supernate total protein to obtain relative incorporation. Means \pm SEM are given. Numbers of animals are given in parentheses.

* $t$ test. tate and glutamate were followed. Because the carboxyl groups of aspartate and glutamate are rapidly exchanging with the bicarbonate pool (which rapidly becomes unlabeled after a single injection of ${ }^{14} \mathrm{CO}_{3}, \mathrm{t}_{1 / 2}$ of $12 \mathrm{~min}$ ), labeled carboxyl groups should be largely replaced by unlabeled groups before reincorporation. Investigators studying liver proteins, on the other hand, have only had to measure radioactivity of the entire protein because all labeled amino acids in liver exchange rapidly with the bicarbonate pool. Our study of a single intestinal protein involved measurement of the radioactivity in the entire protein rather than the aspartate and glutamate constituents. This was necessary because of the small quantities of sucrase-isomaltase protein. Swick and Handa (25) demonstrated that after feeding ${ }^{14} \mathrm{CO}_{3}$, $\sim 10 \%$ of the alpha carboxyl carbon of glutamate and aspartate in intestinal protein was derived from the $\mathrm{CO}_{2}$ pool as well as $10 \%$ of the beta carboxyl carbon of aspartate. In addition about half of the guanidino carbon of arginine and lesser fractions of the carboxyl groups of proline, serine, glycine, and alanine were derived from $\mathrm{CO}_{2}$ fixation (25). Because sucrase-isomaltase is unusually rich in aspartate and glutamate, with 110 and 90 residues per molecule, respectively (26), it seems likely that much of our measured radioactivity was, in fact, from aspartate and glutamate residues. In addition, intestinal mucosa is one of the few tissues besides liver that contains arginase in appreciable quantity (27), which should diminish reincorporation of the labeled guanidino carbon of arginine. These considerations suggest that reincorporation of isotope may not be extensive. The effect of reutilization on apparent halflife, moreover, should be minimal. As Poole (28) has demonstrated, apparent half-lives of proteins that turn over rapidly are much less affected by isotope reincorporation than for proteins that turn over more slowly. The effect of significant reincorporation of isotope on half-lives of proteins with rapid turnover can be better appreciated by considering Millward's results (22) with muscle protein degradation. He found a $t_{1 / 2}$ of $6 \mathrm{~d}$ when radioactivity of aspartate and glutamate was followed (no reutilization) and a $t_{1 / 2}$ of $9.2 \mathrm{~d}$ when radioactivity of all other amino acids in muscle protein was followed (maximum reutilization). We believe, therefore, that the half-lives calculated here are reasonable approximations of the true values.

It is also important to consider the related possibility that the food-induced changes in apparent degradation rate were artefactual, resulting from the changes in the degree of reutilization. Feeding might result in a decrease (by dilution) in the specific activity of labeled amino acids available for reutilization; thus, isotope reutilization might be less and apparent degradation faster. As shown in Fig. 6, however, the feeding period had no appreciable affect on the decline of amino acid specific activity. We believe that this observation and 
our finding of circadian changes in degradation in fasted as well as fed animals (Fig. 5) exclude the possibility.

Determination of protein synthetic rates in intestinal mucosa is difficult for a variety of reasons (21), and we have not attempted a study of sucrase-isomaltase synthesis at different times of the day. Our finding that incorporation of leucine into the protein (Table II) was not different between 0130 and $0930 \mathrm{~h}$ must be regarded as only supportive evidence against circadian changes in synthetic rates (although the data shown in Fig. 6 suggest that major changes in the leucine pool size may not occur during the time of the study). This evidence, however, is strengthened by consideration of the changes in enzyme activity. For example, from 0500 to $1100 \mathrm{~h}$, one can calculate, from the specific activity of the pure enzyme and from the increase in enzyme activity, that total sucrase-isomaltase was increased by 0.77 or $0.13 \mathrm{mg} / \mathrm{h}$. Because degradation is essentially absent during these $6 \mathrm{~h}\left(\mathrm{t}_{1 / 2} 38 \mathrm{~h}\right)$, the value of $0.13 \mathrm{mg} / \mathrm{h}$ probably approximates the enzyme's true synthetic rate during that period. The value is quite similar to the synthetic rate of $0.11 \mathrm{mg} / \mathrm{h}$ found by us previously by analysis of enzyme mass and 24-h decay curves (7). Thus, the observed changes in sucrase-isomaltase protein appear to be compatible with the changes in degradation rates, and do not necessitate postulation of changing synthetic rates. Our concept of the relationship between the degradation rate and enzyme activity is shown in Fig. 7. From 0200 to 1100 h, degradation was almost nonexistent and enzyme levels increased to maximum; thereafter, degradation became

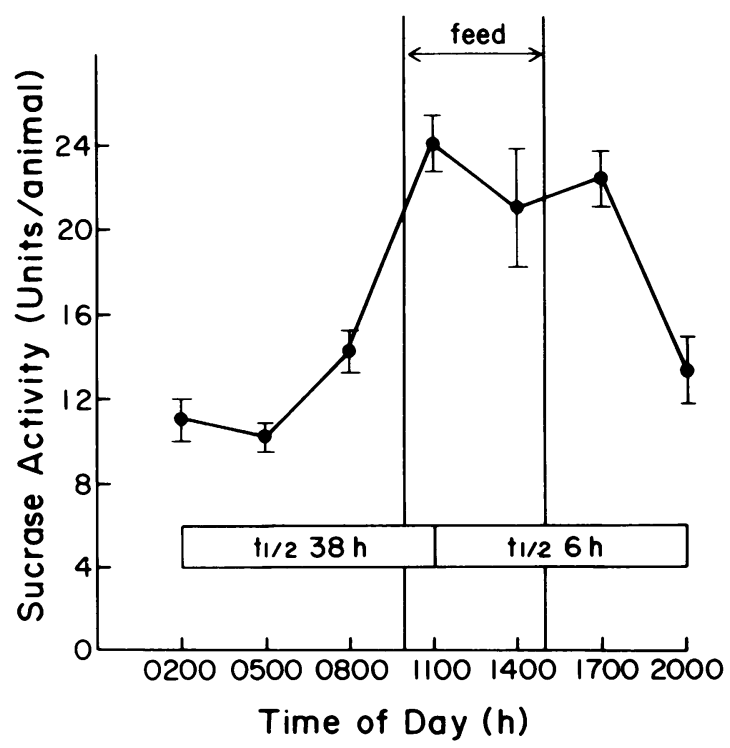

Figure 7 The relationship between sucrase activity and half-life of the enzyme protein. Mean values for four animals \pm SEM are given. Half-lives from the data presented in Fig. 3 are given. rapid and enzyme levels fell. Rapid degradation continued until $0200 \mathrm{~h}$.

Although Figs. 3-5 suggest that the degradation of sucrase-isomaltase is a biphasic process, it is possible that the rapid phase is characterized by more than one rate. This would explain our finding of a $t_{1 / 2}$ of $6 \mathrm{~h}$ in the period from 1100 to $1700 \mathrm{~h}$, and a $\mathrm{t}_{1 / 2}$ of $2.4 \mathrm{~h}$ in the period from 2000 to $0200 \mathrm{~h}$. These calculations were based upon analysis of two different experiments, however, and we believe that further studies with multiple time points within the rapid phase would be necessary to adequately evaluate this possibility.

The obvious question is, What mechanisms are responsible for the variations in degradation rates of sucrase-isomaltase? Sucrase-isomaltase is a relatively large protein $(\sim 210,000 \mathrm{~mol} \mathrm{wt})$ localized anatomically and functionally on the external surface of the brush border membrane $(29,30)$. Work by Alpers' laboratory $(31,32)$ suggests that this protein as well as other surface proteins may be in large part degraded intraluminally, with removal related to the presence of pancreatic enzymes. Thus, ligation of the pancreatic duct (31), pancreatectomy (32), and congenital acinar deficiency (33) all result in a decrease in degradation of large molecular weight brush border proteins. Intestinal mucosal sucrase activity is enhanced in these models as well as in exocrine pancreatic insufficiency in man (34). Finally, administration of cholecystokinin-pancreozymin is known to release sucrase into the intestinal lumen (35). These in vivo studies are supported by in vitro work done by Alpers' laboratory, suggesting that pancreatic elastase will remove sucrase from the brush border membrane $(31,32)$. Thus, cyclical changes in these intraluminal factors could be responsible for alterations in the degradation rate of sucrase-isomaltase.

It is interesting that in two other experimental models of altered sucrase activity, diabetes and sucrose feeding $(7,36-39)$, the mechanism also appears to be a change in the enzyme's degradation rate. Thus, the principal means of regulating sucrase-isomaltase may be through changes in degradation.

\section{ACKNOWLEDGMENTS}

We are grateful to Dr. Robert W. Swick for helpful discussion and to Mr. Dan Omilianowski of the amino acid analysis facility, University of Wisconsin Biophysics Laboratory, for performing the amino acid analyses.

This study was supported by National Institutes of Health grant AM-13927 and by Veterans Administration Research Funds.

\section{REFERENCES}

1. Saito, M. 1972. Daily rhythmic changes in brush border enzymes of the small intestine and kidney in rat. Biochim. Biophys. Acta. 286: 212-215.

2. Saito, M., E. Murakami, and M. Suda. 1976. Circadian 
rhythms in disaccharidases of rat small intestine and its relation to food intake. Biochim. Biophys. Acta. 421: 177-179.

3. Nishida, T., M. Saito, and M. Suda. 1978. Parallel between circadian rhythms of intestinal disaccharidases and food intake of rats under constant lighting conditions. Gastroenterology. 74: 224-227.

4. Stevenson, N. R., F. Ferrigni, K. Parnicky, S. Day, and J.S. Fierstein. 1975. Effect of changes in feeding schedule on the diurnal rhythms and daily activity levels of intestinal brush border enzymes and transport systems. Biochim. Biophys. Acta. 406: 131-145.

5. Stevenson, N. R., and J. S. Fierstein. 1976. Circadian rhythms of intestinal sucrase and glucose transport: cued by time of feeding. Am. J. Physiol. 230: 731-735.

6. Kolínská, J., and J. Kraml. 1972. Separation and characterization of sucrase-isomaltase and of glucoamylase of rat intestine. Biochim. Biophys. Acta. 284: 235-247.

7. Olsen, W. A., and H. Korsmo. 1977. The intestinal brush border membrane in diabetes. J. Clin. Invest. 60: 181-188.

8. Ouchterlony, O. 1958. Diffusion-in-gel method for immunological analysis. Prog. Allergy. 5: 1-78.

9. Kabat, E. A., and M. M. Mayer. 1961. In Experimental Immunochemistry. Charles $\mathrm{C}$ Thomas Publisher, Springfield, Ill. 2nd edition. 72-76.

10. Lowry, O. H., N. J. Rosebrough, A. L. Farr, and R. J. Randall. 1951. Protein measurement with the Folin phenol reagent. J. Biol. Chem. 193: 265-275.

11. Schimke, R. T., E. W. Sweeney, and C. M. Berlin. 1965. The roles of synthesis and degradation in the control of rat liver tryptophan pyrolase. J. Biol. Chem. 240: 322-331.

12. Goldstein, A. 1964. Biostatistics. Macmillan, Inc., New York. 272 pp.

13. Siekevitz, P. 1952. Uptake of radioactive alanine in vitro into the proteins of rat liver fractions. J. Biol. Chem. 195: 549-565.

14. Dahlqvist, A. 1968. Assay of intestinal disaccharidases. Anal. Biochem. 22: 99-107.

15. Porteous, J. W., and B. Clark. 1965. The isolation and characterization of subcellular components of the epithelial cells of rabbit small intestine. Biochem. J. 96: 159-171.

16. Stein, W. H., and S. Moore. 1954. The free amino acids of human blood plasma. J. Biol. Chem. 211: 915-926.

17. Koch, A. L. 1962. The evaluation of the rates of biological processes from tracer kinetic data. I. The influence of labile metabolic pools. J. Theor. Biol. 3: 283-303.

18. Silverblatt, E. R., K. Conklin, and G. M. Gray. 1974. Sucrase precursor in human jejunal crypts.J. Clin. Invest. 53: 76a. (Abstr.)

19. Schimke, R. T. 1970. Regulation of protein degradation in mammalian tissues. In Mammalian Protein Metabolism. H. N. Munro, editor. Academic Press, Inc., New York. 4: $177-228$.

20. Waterlow, J. D., P. J. Garlick, and D. J. Millward. 1978. Protein turnover in mammalian tissues and in the whole body. Elsevier North-Holland, Inc., New York. 371-401.

21. Swick, R. W., and M. M. Ip. 1974. Measurement of protein turnover in rat liver with $\left({ }^{14} \mathrm{C}\right)$ carbonate: protein turnover during liver regeneration. J. Biol. Chem. 249: 6836-6841.

22. Millward, D. J. 1970. Protein turnover in skeletal muscle. I. The measurement of rates of synthesis and catabolism of skeletal muscle protein using ${ }^{14} \mathrm{Na}_{2} \mathrm{CO}_{3}$ to label protein. Clin. Sci. (Oxf.). 39: 577-590.

23. Millward, D. J. 1970. Protein turnover in skeletal muscle. II. The effect of starvation and a protein-free diet on the synthesis and catabolism of skeletal muscle proteins in comparison to liver. Clin. Sci. (Oxf.). 39: 591-603.

24. Chee, P. Y., and J. L. Dahl. 1978. Measurement of protein turnover in rat brain. J. Neurochem. 30: 1485-1493.

25. Swick, R. W., and D. T. Handa. 1956. The distribution of fixed carbon in amino acids. J. Biol. Chem. 218: 577-585.

26. Quaroni, A., E. Gershon-Quaroni, and G. Semenza. 1975. Tryptic digestion of native small-intestinal sucrase-isomaltase complex: isolation of the sucrase subunit. Eur.J. Biochem. 52: 481-486.

27. Herzfeld, A., and S. M. Raper. 1976. Enzymes of ornithine metabolism in adult and developing rat intestine. Biochim. Biophys. Acta. 428: 600-610.

28. Poole, B. 1971. The kinetics of disappearance of labeled leucine from the free leucine pool of rat liver and its effect on the apparent turnover of catalase and other hepatic proteins. J. Biol. Chem. 246: 6587-6591.

29. Alpers, D. H., and B. Seetharam. 1977. Pathophysiology of diseases involving intestinal brush-border proteins. $N$. Engl. J. Med. 296: 1047-1050.

30. Dahlqvist, A., and D. L. Thomson. 1963. The digestion and absorption of sucrose by the intact rat. J. Physiol. (Lond.). 167: 193-209.

31. Alpers, D. H. 1972. Mechanism of rapid disaccharidase turnover in intestinal brush borders. Clin. Res. 20: 447A. (Abstr.)

32. Alpers, D. H., and F. J. Tedesco. 1975. The possible role of pancreatic proteases in the turnover of intestinal brush border proteins. Biochim. Biophys. Acta. 401: 28-40.

33. Kwong, W. K. L., B. Seetharam, and D. H. Alpers. 1978. Effect of exocrine pancreatic insufficiency on small intestine in mouse. Gastroenterology. 74: 1277-1282.

34. Arvanitakis, C., and W. A. Olsen. 1974. Intestinal mucosal disaccharidases in chronic pancreatitis. Am. J. Dig. Dis. 19: $417-421$.

35. Gotze, H., J. W. Adelson, H. B. Hadorn, R. Portmann, and V. Troesch. 1972. Hormone-elicited enzyme release by the small intestinal wall. Gut. 13: 471-476.

36. Das, B. C., and G. M. Gray. 1970. Intestinal sucrase: in vivo synthesis and degradation. Clin. Res. 18: 378A. (Abstr.)

37. Deren, J. J., S. A. Broitman, and N. Zamcheck. 1967. Effect of diet upon intestinal disaccharidases and disaccharide absorption. J. Clin. Invest. 46: 186-195.

38. Rosensweig, N. S., and R. H. Herman. 1968. Control of jejunal sucrase and maltase activity by dietary sucrose or fructose in man. J. Clin. Invest. 47: 2253-2262.

39. Rosensweig, N. S., and R. H. Herman. 1969. Time response of jejunal sucrase and maltase activity to a high sucrose diet in normal man. Gastroenterology. 56: $500-505$. 